\title{
Dynamics of Fagus sylvatica L. Necrotization under Different Pollutant Load Conditions
}

\author{
Ivan Mihál ${ }^{1 *}$, Róbert Marušák², Milan Barna ${ }^{1}$ \\ ${ }^{1}$ Institute of Forest Ecology, Slovak Academy of Sciences, Zvolen, Slovakia \\ ${ }^{2}$ Faculty of Forestry and Wood Sciences, Czech University of Life Sciences, Praha, Czech Republic
}

Received: 27 February 2018

Accepted: 12 June 2018

\begin{abstract}
The potential impact of acidic fluorine type of pollutants on the dynamics of European beech (Fagus sylvatica L.) stem bark and crown disease was investigated between 2004 (2007) and 2014 in three mature beech stands in Central Europe. The localities were $1.5 \mathrm{~km}, 7 \mathrm{~km}$ and $18 \mathrm{~km}$ from the pollution source: an aluminium plant. A decrease of necrotic disease with the increasing distance from the pollution source was revealed. Necrotization was highest nearest to the pollution source. The significance of the impact of necrotic disease was confirmed for the $2^{\text {nd }}$ and $3^{\text {rd }}$ tree classes. Necrotization was quantified using the indices of stem necrotization $\left(\mathrm{I}_{\mathrm{SN}}\right)$, crown necrotization $\left(\mathrm{I}_{\mathrm{CN}}\right)$ and necrotization of whole tree $\left(\mathrm{I}_{\mathrm{WTN}}\right)$. Over the period 2004 (2007)-2014, the values of $\mathrm{I}_{\mathrm{SN}}, \mathrm{I}_{\mathrm{CN}}$ and $I_{\text {WTN }}$ decreased at all three localities. Significant positive relationships were found between the necrotization of the crown and stem of the same tree at all localities (Spearman's correlation analyses $\mathrm{R}=0.764 ; 0.597$ and $0.755, P=0.001 ; 0.01$ and 0.001 ). Accordingly, the trees suffered from the necrotic damage at all parts in relation to their current health state.
\end{abstract}

Keywords: aluminium smelter, beech bark disease, necrotic damage, European beech, Western Carpathians

\section{Introduction}

European beech (Fagus sylvatica L.) is an important tree species due to its high representation in the forests of Slovakia and also throughout Central Europe. Since the late 1980s, an increased incidence of beech bark necrotic disease has reached the level of epiphytotic disease in Slovakia. Beech necrotic disease has also drawn attention in other Central and Southeast

*e-mail:mihal@ife.sk
European countries, including the Czech Republic, Poland, Hungary, Romania, Serbia and Bulgaria [1].

Outside Europe, necrotic disease occurs on American beech (Fagus grandifolia Ehrh.) in North America [2]. The symbiotic insect-fungal disease complex, beech + Cryptococcus fagi Bärensp. + Nectria spp. = Beech Bark Disease (BBD), is a basic model of the beech bark necrotic disease in North America and Europe. The effect of Cryptococcus fagisuga Lindinger as a necessary predisposing factor to infection of American beech with fungi of the genus Neonectria Wollenw. has been studied extensively [3].

Other subspecies or forms of Fagus sylvatica in European countries are also affected by BBD to 
varying degrees. For example, in a part of southeastern Europe, necrotic beech bark disease was observed on a subspecies, Fagus sylvatica ssp. orientalis Lipsky [syn: Fagus moesiaca (K. Malý) Czeczott]. According to some Serbian authors, the necrotic beech bark disease in Serbia is caused by a synergic action of infection agents, Cryptococcus fagi Bärensp.+ Nectria spp. Similarly, in southeastern Bulgaria, Fagus moesiaca had lower levels of stem necrotization compared to Fagus sylvatica [1].

In several European countries, the level of concern regarding beech necrotic disease depends on the rate of spread of the disease or the current state of the research. In Germany, the degree of necrotic damage to beech in relation to site conditions as well as beech bark wounds caused by felling have been evaluated [4]. In the Czech Republic, the symptoms and diagnostics of beech necrotic disease have been described and also the current health state of beech stands and projected stand dynamics using a growth simulator SIBYLA has been evaluated under strong air pollutant loads in the Giant Mountains in northern Bohemia [5]. The accumulation of fluoride in bark and leaves of forest trees around the aluminium plant in Norway was evaluated [6]. The soil microbial and enzyme activities response to pollution near an aluminium smelter in Žiar nad Hronom (central Slovakia) were also studied [7]. Research has been conducted on the effects of air pollution, for example of heavy metals in beech stands and in beech leaf litter in relation to the health status of beech stands investigated in Poland $[8,9]$.

In Slovakia, extensive research on beech necrotic disease has been conducted, including the development of original methods to evaluate necrotization, descriptions of several symptoms of the disease, wood injury, quantification of the disease related to the sociological position of trees in the stand and the abundance of the disease related to pollutant loads of various localities [10-14]. From the above, it can be seen that the issue of beech bark necrotic damage and beech stand mortality is a serious phytopathological problem practically everywhere in the world where the representatives of the genus Fagus s.l. occur. The BBD dynamics in beech stands can be corrected to a certain extent by various forestry measures, e.g., the interesting data about BBD dynamics in beech thinning forests were obtained in Central Slovakia [15]. In these stands we applied the methods of selective support of target trees combined with a sanitary negative selection of heavily necrotically attacked beech trees. After several thinnings, we found that necrotic damage to target trees fell from $14.5 \%$ to $9.1 \%$ compared to $40.3 \%$ in unmanaged necrotic beech forests.

BBD also manifests significantly on the structure, anatomy and physico-mechanical properties of wood. The dynamics of changes in beech wood after bark injury was studied [16]. We found that a narrow dark "reaction zone" is formed at the edges of the lesions, characterized by high vascular tylatation and concentration of polyphenolic compounds. The reaction zone separates the necrotic tissue from the physiologically active tissue. These changes have a negative impact on the structure and strength of the wood. Similarly, the changes in the anatomy of the bark and wood tissues of Malus domestica attacked by the fungus Neonectria ditissima have been described. We found that the callus anatomy formed after the injury showed closed tumour features with a marked disorganization of the wood elements influenced by Neonectria ditissima infection spread in bark and cambium [17].

Necrotic damage to beech bark tissues is associated with activity or interaction among various insect and fungal pathogens, mainly fungi of the genus Anthostoma Nitschke, Cytospora Ehr.:Fr., Diatrype Fr., Fusarium Link, Nectria (Fr.) Fr., Neonectria Wollenw., Ophiostoma Syd., and fungal-like organisms Phytophthora de Bary, also Phomopsis Sacc., Valsa Fr. and Verticillium Nees, etc. Recent views on the aetiology of BBD indicate that the primary Phytophthora infections of stem bark are triggered by climatic extremes and that it is a major factor in the BBD complex in central Europe [1, 14, 18-19].

Based on the number of scientific outputs which pointed at the negative impact of pollutants from Žiar smelter (defoliation: [20], physiology - chlorophyll, fluorescence: [21], herbs and fungi: [22], soil: [7, 23], forest stand: [24]), our aim was to assess this effect on the occurrence of the necrotic disease of mature beech stands.

As a working hypothesis, we expect that the value of necrotization of beech stems and crowns: i) will increase over time, ii) will exhibit a positive correlation with the exposure to pollutant loads and iii) will show a significant relationship between the necrotic disease of a beech stem and its crown. In this study we focused on evaluating the consequences of BBD on the stems and crowns of trees in different environmental conditions, regardless of the primary fungal causative agents of the disease.

\section{Material and Methods}

\section{Study Area}

This study was conducted in three localities (Table 1) within submontane beech forests of the Western Carpathians (Central Europe, Central Slovakia). The Žiar locality is situated in the Štiavnické vrchy Mountains, located $1.5 \mathrm{~km}$ from an aluminium plant in Žiar nad Hronom; it was formerly under the immediate influence of pollutants, acidic fluorine-type emissions in the zone of pollutant threat A [25]. Since 1996, when a new modern plant with significantly reduced emissions began its operation, pollutant emissions from the aluminium plant have been significantly reduced (Table 2). Despite the pollutants-reducing measures implemented, the damage to the surrounding environment seems to be a long-lasting problem [26]. 
Table 1. Description of research localities in Slovakia.

\begin{tabular}{|c|c|c|c|}
\hline Characteristics & Žiar & Jalná & Kováčová \\
\hline Geographic coordinates & $\begin{array}{l}48^{\circ} 35^{\prime} 15^{\prime \prime} \mathrm{N} \\
18^{\circ} 51^{\prime} 05^{\prime \prime} \mathrm{E}\end{array}$ & $\begin{array}{l}48^{\circ} 33^{\prime} 98^{\prime \prime} \mathrm{N} \\
18^{\circ} 56^{\prime} 93^{\prime \prime} \mathrm{E}\end{array}$ & $\begin{array}{l}48^{\circ} 38^{\prime} 10^{\prime \prime} \mathrm{N} \\
19^{\circ} 04^{\prime} 08^{\prime \prime} \mathrm{E}\end{array}$ \\
\hline Aspect & NW & $\mathrm{W}$ & SW \\
\hline Prevailing wind direction & NW & $\mathrm{N}$ & NW \\
\hline Altitude (m a.s.l) & 470 & $610-620$ & $480-510$ \\
\hline Slope $\left({ }^{\circ}\right)$ & 5 & 15 & $13-20$ \\
\hline Geological substrate & $\begin{array}{l}\text { Ryolite and ryodacites } \\
\text { tuffits agglomerates }\end{array}$ & $\begin{array}{l}\text { Andesite tuffits } \\
\text { agglomerates }\end{array}$ & $\begin{array}{l}\text { Andesite tuffits } \\
\text { agglomerates }\end{array}$ \\
\hline Soil & cambisol, acid pseudogley & $\begin{array}{l}\text { cambisol modal, } \\
\text { slightly acid }\end{array}$ & $\begin{array}{l}\text { cambisol modal, } \\
\text { saturated }\end{array}$ \\
\hline $\mathrm{pH}\left(\mathrm{H}_{2} \mathrm{O}\right) *$ & 5.0 & 5.8 & 6.3 \\
\hline Mean annual precipitation (mm) & 636 & 850 & 660 \\
\hline Mean annual temperature $\left({ }^{\circ} \mathrm{C}\right)$ & 9.2 & 6.2 & 8.3 \\
\hline Forest types & $\begin{array}{l}\text { Fagetum pauper } \\
\text { superiora }\end{array}$ & Querceto-Fagetum & $\begin{array}{l}\text { Fagetum pauper } \\
\text { inferiora }\end{array}$ \\
\hline Plant association & $\begin{array}{c}\text { Dentario } \\
\text { bulbiferae-Fagetum }\end{array}$ & $\begin{array}{c}\text { Dentario } \\
\text { bulbiferae-Fagetum }\end{array}$ & $\begin{array}{l}\text { Dentario bulbiferae-Fagetum, } \\
\text { Carici pilosae-Fagetum }\end{array}$ \\
\hline Stand age (years) & $80-100$ & $90-100$ & $110-115$ \\
\hline Tree species composition (\%) & Beech 98, oak 2 & $\begin{array}{c}\text { Beech 98, oak 1, hornbeam } \\
1\end{array}$ & $\begin{array}{l}\text { Beech } 95, \text { fir } 2, \\
\text { hornbeam } 2 \text {, oak } 1\end{array}$ \\
\hline Stocking & 0.7 & 1.0 & 1.0 \\
\hline Crown cover $(\%)$ & 95 & 97 & 97 \\
\hline Pollutant source distance (km) & 1.5 & 7 & 18 \\
\hline $\begin{array}{l}\text { Wet deposition** }\left(\mathrm{kg} . \mathrm{ha}^{-1}\right) \\
\mathrm{SO}_{4}^{2-} \\
\mathrm{F}^{-}\end{array}$ & $\begin{array}{c}26.3 \\
2.5\end{array}$ & $\begin{array}{l}\text { not measured } \\
\text { not measured }\end{array}$ & $\begin{array}{c}18.1 \\
0.4\end{array}$ \\
\hline
\end{tabular}

* Median values of $\mathrm{pH}$ measured at a depth of 1 to $6 \mathrm{~cm}$ in the year 2013

** according to [43]

The forest stands of the Žiar are categorized as "special protective forests" from which any forest logging activities are excluded due to the ongoing air pollutant load and insufficient natural regeneration of forest stands.

The Jalná locality, situated in the Štiavnické vrchy Mountains, is located $7 \mathrm{~km}$ from Žiar. The stand of mature trees has developed naturally with no management intervention over the last 65 years [27]. The Kováčová locality is situated in the Kremnické vrchy Mountains and lies $18 \mathrm{~km}$ from Žiar. This stand of mature trees has developed naturally with no management intervention over the last 35 years [28, 29].

\section{Evaluation of Necrotic Damage}

Field assessments were conducted in 2004 (stems), 2007 (crowns) and 2014 (stems and crowns - whole trees) in autumn or spring months, when beech crowns were leafless. Only predominant, dominant

Table 2. Mean pollutant emission estimates $( \pm \mathrm{SE})$ from the aluminium smelter in Žiar nad Hronom (t.yrs $\left.{ }^{-1}\right)$ for the following periods: 1993-1995 (old smelter technology); 1996-1999 (new smelter technology); 2000-2006 (period prior to this study); $2007-2013$ (period before our second evaluation in 2014).

\begin{tabular}{|c|c|c|c|c|}
\hline Pollutants & $1993-1995$ & $1996-1999$ & $2000-2006$ & $2007-2013$ \\
\hline $\mathrm{HF}$ & $331 \pm 15$ & $51 \pm 14$ & $26 \pm 4$ & $19 \pm 3$ \\
\hline $\mathrm{SO}_{2}$ & $2889 \pm 486$ & $1318 \pm 121$ & $1246 \pm 34$ & $1395 \pm 23$ \\
\hline
\end{tabular}

HF hydrogen fluoride; $\mathrm{SO}_{2}$ sulfur dioxide; Source: https://www.slovalco.sk/ [accessed 07. 07. 2015] 

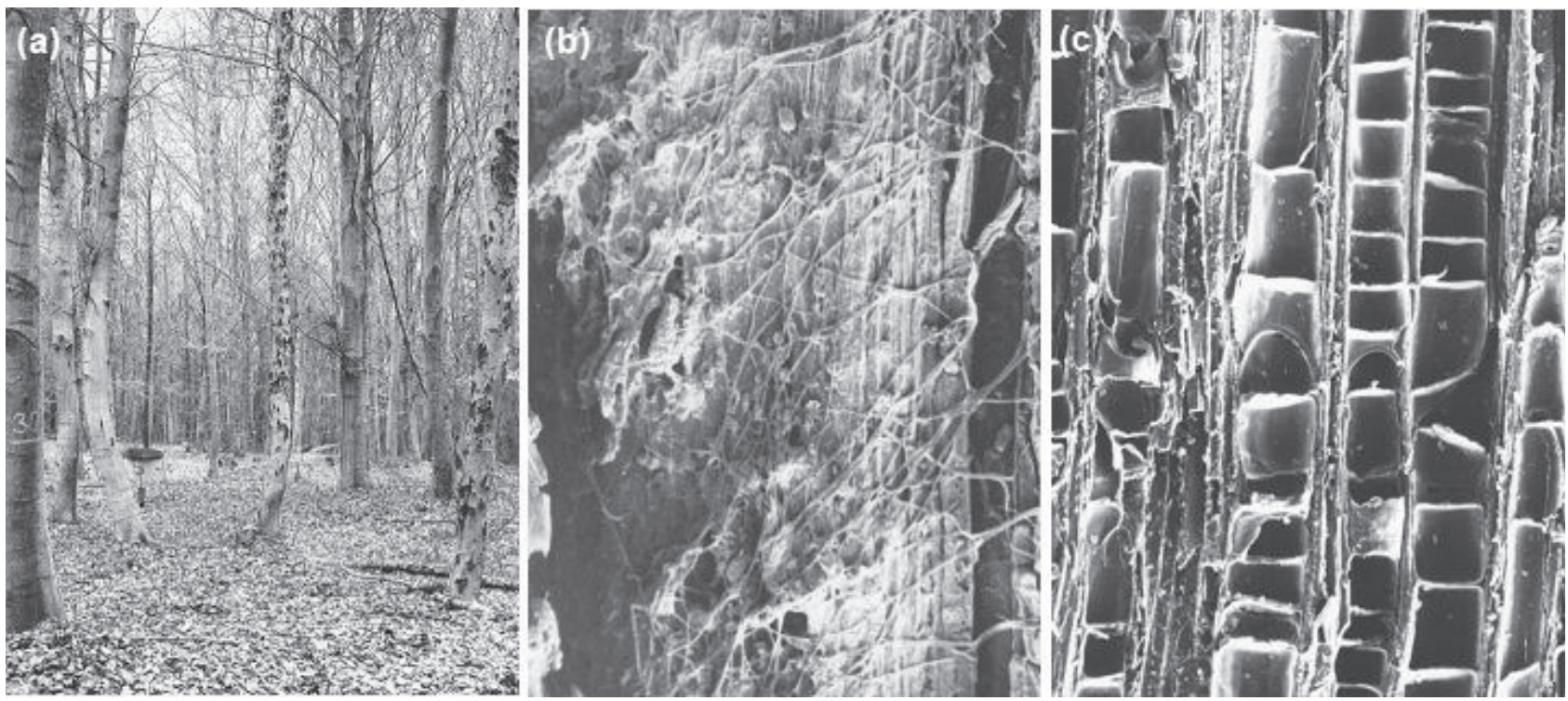

Fig. 1. a) Beech stand significantly impacted by necrotic disease at Žiar, b) parasitic fungus mycelium inside necrotic wound in beech bark at Jalná (scanning electron microscope, magnification $340 \times$ ) and c) vessel tyloses in necrotic beech wood at Jalná (scanning electron microscope, magnification $580 \times$ ).

and codominant trees corresponding to the Kraft tree classes of 1,2 and 3, respectively, qualified as sample trees for the purpose of crown and stem condition assessment. Belonging to a specific social class reflects a position of a tree in a stand, and through this, its growth potential. Individual trees representing each class were selected at such a distance from each other that ensured that they do not affect each other, at least to an average height of stand $(25 \mathrm{~m})$. The evaluations were repeated 10 years (or seven year in the case of crowns) after the first measurements. We analyzed only the trees that survived until the last measurements. In 2014 we evaluated the same live trees that were marked and also evaluated in 2007. The data representing the trees that died between 2004 and 2014 were excluded from the analysis. We evaluated five trees of each tree class. For each locality we evaluated 15 samples [30].

To assess the degree of necrotic damage to beech stems (Fig. 1a) in a locality, all trees were assigned one of five degrees of stem bark necrotization - ranging from 0 , stems without necrosis, to 4 , stems with large necrosis that can cause stem breakage. To compare the degree of stem necrotization among localities, we reduced the stem necrotic damage assessment to a single value for the entire stand based on the index of stem necrotization $\left(\mathrm{I}_{\mathrm{SN}}\right)$ [31]. The $\mathrm{I}_{\mathrm{SN}}$ is the average value of the degree of stem necrotization of all trees in a locality. The calculation of $\mathrm{I}_{\mathrm{SN}}$ is as follows:

$$
I_{S N}=\frac{0 n_{0}+1 n_{1}+2 n_{2}+3 n_{3}+4 n_{4}}{n_{0}+n_{1}+n_{2}+n_{3}+n_{4}}
$$

... where:

$I_{S N} \quad-$ index of stem necrotization

0 to 4 - degrees of beech stem necrotization

$\mathrm{n}_{0}$ to $\mathrm{n}_{4}$ - the number of trees within different degrees of necrotization

To evaluate necrotization of branches in beech crowns, we used a scale based on four degrees $(0,1,2$, 3) [10]. A greater number of degrees would considerably undermine the objectivity of the evaluation because of the difficulty in accessing the crown. The presence and degree of necrosis in the upper part of the stem and branches in crowns of tall trees were often assessed using binoculars. To evaluate the degree of necrotic disease of the whole tree, we developed a scale that is a combination of the degree of necrotic damage to the stem and the crown for each tree (Table 3). Similar to $I_{S N}$, we calculated an index of crown necrotization $\left(\mathrm{I}_{\mathrm{CN}}\right)$ to summarize crown necrosis at the stand level as well as an index of whole tree necrotization for each locality (index of whole tree necrotization $-\mathrm{I}_{\mathrm{WTN}} ;[10]$ ). The value of $\mathrm{I}_{\mathrm{wTN}}$ reflects the current overall state of necrotization of a particular tree, as well as necrotization of the entire beech stand in space and time; space refers to the assessment of necrotization on the stem from the buttress roots to the top branches in the crown, and time refers to the observed period of seven years for this study: 2007 to 2014. Necrotic diseases are also caused by fungi infections (Fig. 1b), leading to typical symptoms of the disease of tracheomycotic type, e.g., creation of vessel tyloses (Fig. 1c).

\section{Statistical Analyses}

We compared the frequency of necrotic disease of beech stems and crowns depending on the distance of 
Table 3. Combination scale of degree of stem necrotization and degree of crown necrotization.

\begin{tabular}{|c|c|c|c|c|}
\hline \multirow{2}{*}{$\begin{array}{c}\text { Degree of stem } \\
\text { necrotization (A) }\end{array}$} & \multicolumn{4}{|c|}{ Degree of crown necrotization (B) } \\
\cline { 2 - 5 } & 0 & 1 & 2 & 3 \\
\hline 0 & 0 & 0 & 1 & 1 \\
\hline 1 & 1 & 1 & 2 & 2 \\
\hline 2 & 2 & 2 & 3 & 3 \\
\hline 3 & 3 & 3 & 3 & 3 \\
\hline 4 & 4 & 4 & 4 & 4 \\
\hline
\end{tabular}

(A): 0 - without any necrotic wounds of bark, 1 - small necrotic wounds (bark fissures, cracks) occurring as single ones or in solitary groups, visible at closer examination of the stem only, 2 - small necrotic wounds (like degree 1) accompanied by occurrence of larger necrotic wounds (larger fissures, rugged bark) visible at ordinary examination of the stem, 3 - larger necrotic wounds denuding the xylem and partly deforming the stem, bark cracking and shedding, visible already at a larger distance from the stem, 4 - large necrotic wounds heavily deforming the stem or leading to "break necrosis", rugged bark and shedding, visible from a distance.

(B): 0 - no necrotic wounds, 1 - small, insignificant necrotic wounds, occurring individually or in groups, 2 - same as degree 1 , together with occurrence of larger but unopened necrotic wounds, 3 - same as degree 2 , together with the occurrence of large open wounds and so called "breakthrough" necrotic wounds.

pollution source using $3 \times 3$ contingency tables, which were analyzed with a chi-square test $\left(\chi^{2}\right)$ for differences between medians, because the sample sizes were small and abnormally distributed [32]. Five degrees of beech stem necrotization $(0,1,2,3,4)$ were merged to three degrees. In the first and second tree classes we merged the second, third and fourth degrees of the disease $(2+3+4)$ into one group because the occurrence frequencies of the last two degrees were very low, often zero. For the same reason, in the third tree class we merged the first and second degrees into one group and the third and the fourth degrees into another group $(1+2,3+4)$. A similar procedure was performed with the crown data, except for the fourth degree. This analysis allowed us to evaluate the temporal dynamics of the health state by comparing the results in 2004 (2007) and 2014. Spearman correlation analysis was performed to determine the relationship between the necrotic disease of stem $(0,1,2,3,4)$, and the necrotic disease of crown $(0,1,2,3)$ of the same tree. All statistical analyses were performed using STATISTICA software ver. 9.0 (Stat Soft Inc., Tulsa OK, USA).

\section{Results}

As the distance from the pollution source increased, we recorded the decrease of the necrotic disease values (Fig. 2). In 2004, this trend was significant for stem disease of trees in the $2^{\text {nd }}$ and $3^{\text {rd }}$ tree class $(\chi 2=7.80,9.50 \mathrm{P}=0.0202 ; 0.0497)$, while in 2014 it was significant only in the $3^{\text {rd }}$ tree class $(\chi 2=29.10$, $\mathrm{P}=0.0358$, Table 4). The developmental patterns of stem necrotization between 2004 and 2014 were similar at all localities (Fig. 2a). During the study period, necrotization was more frequent in Žiar, i.e., the locality closest to the pollution source, compared to the stands in Jalná and Kováčová, which are 7 and $18 \mathrm{~km}$ away from the emission source, respectively. The trend of disease in crowns is similar, but the difference between localities is less marked (Fig. 2b). The effect of the distance from the pollution source on the health state of beech crowns was not significant anywhere, although in $2007 P<0.1$ was found in the $1^{\text {st }}$ tree class.

Spearman's correlation analyses significant relationships between the necrotic damages to the stems and crowns at all localities (Fig. 3). The relationship between the necrotic disease of beech stems and crowns showed a positive correlation (Fig. 3). Trees suffer from necrotic damage to all parts equally, as related
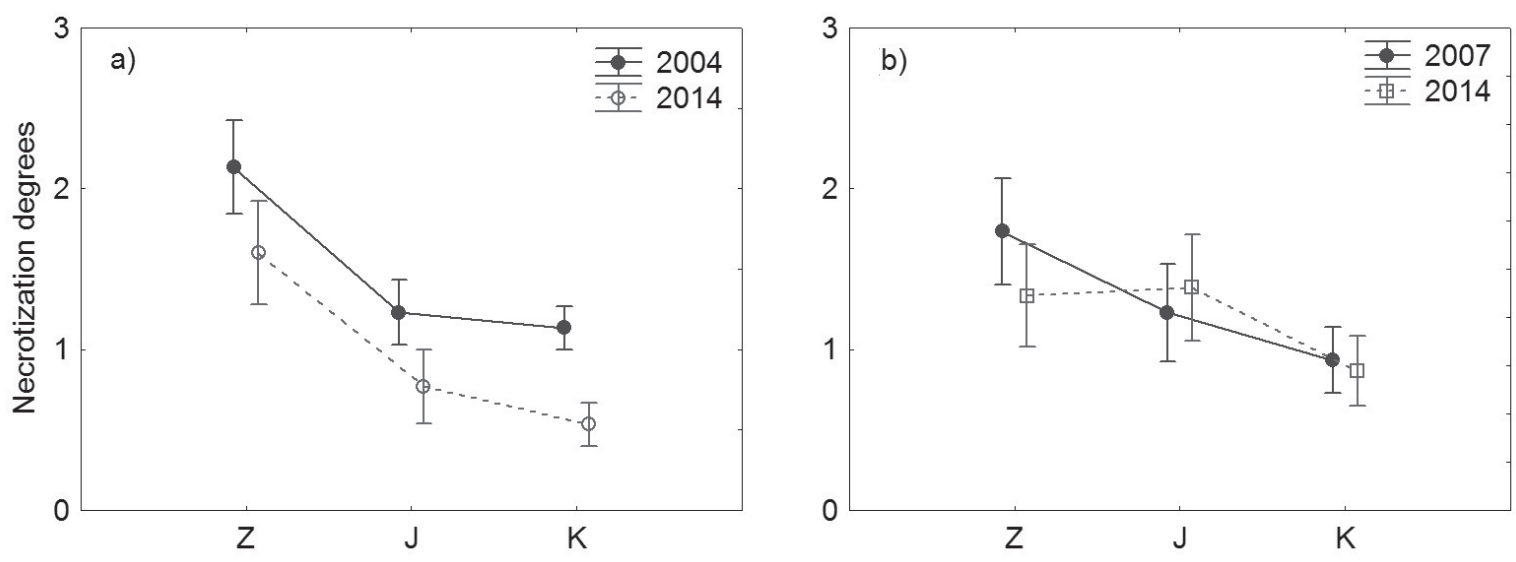

Fig. 2. Dynamics of beech bark disease (necrotization degrees) on the stem a) and crown b) of European beech trees in researched localities (Z - Žiar, J - Jalná, K - Kováčová); error bars show SE. 
Table 4. Chi-square test analysis $(\chi 2)$ of health by degrees of necrotic diseases of beech in tree classes for localities at different distances from aluminium smelter in 2004 (2007) and 2014.

\begin{tabular}{|c|c|c|c|c|c|c|c|c|c|c|}
\hline & & \multicolumn{9}{|c|}{ Tree class } \\
\hline & & \multicolumn{3}{|c|}{1} & \multicolumn{3}{|c|}{2} & \multicolumn{3}{|c|}{3} \\
\hline & & $\chi^{2}$ & $\mathrm{df}$ & $P$ & $\chi^{2}$ & $\mathrm{df}$ & $P$ & $\chi^{2}$ & $\mathrm{df}$ & $P$ \\
\hline \multirow{2}{*}{ Stem } & 2004 & 4.40 & 4 & 0.3545 & 7.80 & 2 & 0.0202 & 9.50 & 4 & 0.0497 \\
\hline & 2014 & 6.80 & 4 & 0.1468 & 4.20 & 4 & 0.3796 & 10.29 & 4 & 0.0358 \\
\hline \multirow{2}{*}{ Crown } & 2007 & 8.70 & 4 & 0.0691 & 4.90 & 4 & 0.2977 & 4.75 & 4 & 0.3139 \\
\hline & 2014 & 3.00 & 4 & 0.5578 & 3.10 & 4 & 0.5412 & 1.67 & 2 & 0.4346 \\
\hline
\end{tabular}

bold: $P<0.05$

to the state of their current health. Although the effect of distance from emission source or the health state of stands on the strength of the relationships was not confirmed, the greatest frequency of trees with little or no necrosis (necrotization degrees 1 and 0) was reported from the stands least affected by pollutants at Kováčová (Fig. 3c). On the contrary, the greatest number of most damaged trees was found on the locality Žiar $1.5 \mathrm{~km}$ from the smelter (Fig. 3a). Spearman's R correlation indicated that necrotic disease of crowns and stems was not significant when analysing the values of stems in 2004 and values of crowns in 2007.

From 2004 (2007) to 2014, all localities exhibited decreased necrotization index values for stems, crowns and whole trees, with the exception of a small increase of $\mathrm{I}_{\mathrm{CN}}$ in the case of Jalná (Table 5). Index values for stems, crowns and whole trees were always higher in Žiar compared to Jalná and Kováčová.

\section{Discussion}

We observed different dynamics of beech necrosis in the stems and crowns of European beech trees (Fig. 2). Between 2004 and 2014, a decrease of the occurrence of stem necroses was found in all localities, although there were no significant changes in the level of crown necrotization. However, to justify the significant differences between all localities we would need to extend the evaluated set of trees. This is an interesting result because we expected the opposite trend - deterioration in the health of infested trees, as observed between 1997 and 2006 in the Stolické vrchy Mountains, where a decline in the number of individual trees in degrees 0 and 1 and hence, the increase in the number of trees in degree 2 was observed over a period of 10 years [12].

During our research we found an interesting species, Biscogniauxia nummularia, as a latent factor of infestation in Fagus sylvatica. Similarly, research in Italy suggested that $B$. nummularia was a parasitic and necrotrophic fungus in beech forests in southern Italy (Campania region) [33, 34]. In the context of works [33, 34] we can conclude that B. nummularia was found on dying beech branches in the Jalná and Kováčová localities; however, at Žiar, where pollutant loads were highest, this fungus was not identified.

We observed improved stand health conditions with increased distance from the emission source. In the past the increase of $\mathrm{I}_{\mathrm{SN}}$ value in Žiar, from 1.77 in 1995 to 2.20 in 2004, was recorded [11]. The health state of beech (defoliation) at Žiar was significantly worse than at Jalná and Kováčová, which are $7 \mathrm{~km}$ and $18 \mathrm{~km}$ from the emission source, respectively. Unfavourable health conditions of beech stands in Žiar, due to the load of fluorine-type pollutants, were reflected not only
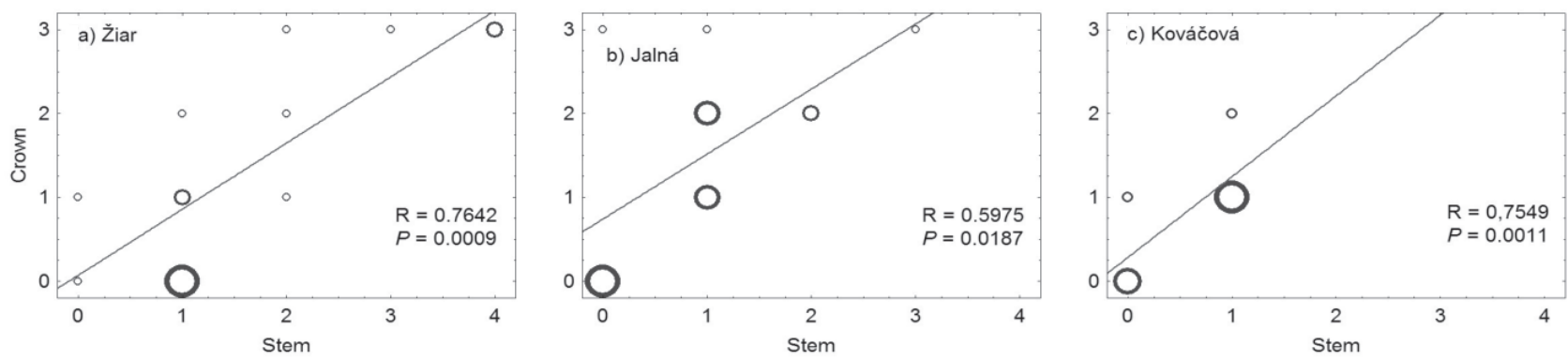

Fig. 3. Bubble chart of correlation between necrotization degrees of stem and crown of the same trees (in 2014); $P$ is the probability for $\mathrm{R}$, Spearman's coefficient; the sizes of the bubbles are determined by the values of abundance (the smallest -1 , the biggest -6 ) 
Table 5. Indices of necrotization of stems (2004 and 2014), crowns (2007 and 2014) and whole trees in study localities (2014).

\begin{tabular}{|c|c|c|c|c|c|c|}
\hline \multirow{2}{*}{$\begin{array}{c}\text { Index of } \\
\text { necrotization }\end{array}$} & \multicolumn{2}{|c|}{ Žiar } & \multicolumn{2}{|c|}{ Jalná } & \multicolumn{2}{c|}{ Kovácová } \\
\cline { 2 - 7 } & $2004(2007 *)$ & 2014 & $2004(2007 *)$ & 2014 & $2004(2007 *)$ & 2014 \\
\hline $\mathrm{I}_{\mathrm{SN}}$ & 2.13 & 1.60 & 1.45 & 0.77 & 1.13 & 0.53 \\
\hline $\mathrm{I}_{\mathrm{CN}}{ }^{*}$ & 1.73 & 1.33 & 1.61 & 1.38 & 0.93 & 0.87 \\
\hline $\mathrm{I}_{\mathrm{WTN}}$ & - & 1.8 & - & 1.15 & - & 0.66 \\
\hline
\end{tabular}

$* \mathrm{I}_{\mathrm{CN}}-2007$

$\mathrm{I}_{\mathrm{SN}}$ - index of stem necrotization (see Material and methods)

$\mathrm{I}_{\mathrm{CN}}-$ index of crown necrotization (see Material and methods)

$\mathrm{I}_{\mathrm{WTN}}-$ index of whole tree necrotization (see Material and methods)

in the high values of defoliation $(25-49 \%)$ but also in the mortality of trees that reached $21 \%$ over the period 1991 to 2004 [35]. The permanent loss of foliage in beech stands (up 74\%) has been recorded in the Czech Republic, which may be a reason for the continuing long-term effects of ambient pollution and its effects on soil quality [5]. The high values of the fluoride-type immissions in Žiar were reflected in the high defoliation values of beech trees, but also in the mortality of trees, which reached 21\% between 1991 and 2004 [36].

Soil microbial activity in the vicinity of our research plot in Žiar was also studied [7]. Aluminium ions $\left(\mathrm{Al}^{3+}\right)$ play a significant role in biogeocenosis, where acid fluorine pollutants are concentrated, such as the soils around the aluminium plant. From our previous work at Žiar locality [36] and other works [37], it is known that $\mathrm{Al}^{3+}$ chelates, which are especially toxic to mycelium of ectomycorrhizal fungi, were released from the soil in the forests near the aluminium plant. Low representation of ectomycorrhizal fungi in forests under the impact of magnesite-type immissions was also found in Slovakia $[37,38]$. Only one ectomycorrhizal species was found in the worst degradation zone $\mathrm{A}$, and 23 species of ones were found in the least attacked degradation zone D. The ectomycorrhizal potential values ranged from 0.0 in stage A to 0.56 in stage D $[37,38]$.

Similarly, other results indicated that woody plants native to acid soils have evolved various strategies to overcome $\mathrm{Al}^{3+}$ stress [39]. One such strategy is the exclusion of $\mathrm{Al}^{3+}$ from root tips, probably through the release of organic acid anions. The formation of ectomycorrhizal structures, which are capable of accumulating $\mathrm{Al}$ in the cell walls of hyphal cells, may also be regarded as an exclusion strategy by reducing the degree of contact of root cells to $\mathrm{Al}^{3+}$.

Necrotic wounds in the suppressed trees $\left(4^{\text {th }}\right.$ and $5^{\text {th }}$ tree classes according to Kraft) are too big for trees to fully heal. However, callous production over necrotic wounds of trees in the $1^{\text {st }}$ to $3^{\text {rd }}$ tree classes is possible; higher vitality of trees in these classes in comparison to trees in the $4^{\text {th }}$ and $5^{\text {th }}$ tree classes also plays an important role. The necrotization process can be negative, i.e., the addition of further necroses, enlargement of the existing ones, etc. However, it can have a positive effect, i.e., a healing process is taking place, particularly the healing of small necrotic wounds. Because of this, the changes in the necrotization process can take place very slowly [1]. We observed that the changes in the necrotization process can be very slow and are not necessarily significant, even over several years, as observed in the beech stems bark necrotization index comparison at the same locality nine years later [12].

Necrotization in beech crowns was different compared to necrotization in stems. Note that in our localities, the index values of crown necrotization $\left(\mathrm{I}_{\mathrm{CN}}\right)$ were in the range from 1.73 in Žiar to 0.93 in Kováčová. In contrast, the index values of stem necrotization $\left(\mathrm{I}_{\mathrm{SN}}\right)$ ranged from 2.13 in Žiar to 1.13 in Kováčová. In Slovakia 54 sites where the range of average values of $\mathrm{I}_{\mathrm{SN}}$ was very wide were sampled, from 0.53 to 1.97 (1.22 on average) [1]. The value of $\mathrm{I}_{\mathrm{SN}}$ at Žiar was as high as 2.13 in 2004, but then declined to 1.6 in 2014; a similar pattern was also observed in the remaining two localities (Table 5). We have always recorded lower values of $\mathrm{I}_{\mathrm{CN}}$ compared to the values of $\mathrm{I}_{\mathrm{SN}}$, (except for a modest increase of $\mathrm{I}_{\mathrm{CN}}$ in the case of Jalná and Kováčová), virtually everywhere, which may be due to the different dynamics of necrotization in beech stems and crowns. The lower $\mathrm{I}_{\mathrm{CN}}$ value compared to the $\mathrm{I}_{\mathrm{SN}}$ value at Žiar in 2014 is surprising because we have so far recorded worse necrotic crown damage than stems (for example, during our research in Poland [40] and Bulgaria [41], the $\mathrm{I}_{\mathrm{CN}}$ values were always higher than $\mathrm{I}_{\mathrm{SN}}$ values). It appears that the revitalization process of beech stands is ongoing at Žiar, which has also been reflected in lower necrotic damage of beech crowns.

Our results indicate that BBD is a pressing issue that requires increased scrutiny [1]. A significant increase in beech necrotic disease that has been recorded in Slovakia since the end of the 1980s may be part of a natural cycle, which is characteristic of the majority of parasitic diseases, and it may be connected to ongoing processes of global climatic changes. Beech bark disease may pose a serious risk to many European forests; management recommendations should rely on long-term monitoring of this phytopathological phenomena. The pressing nature of this issue is evident in the conclusions and recommendations of the Man and the Biosphere 
Programme Strategy report of UNESCO to support mitigation and adaptation to climate change and other aspects of global environmental change [42].

\section{Conclusions}

We quantified the dynamics of necrotic disease of beech stems and crowns as well as the whole tree (BBD - beech bark disease) in mature stands exposed to long-term pollutants of acid fluorine in Slovakia. The study was conducted between 2004 (2007) and 2014 in three localities: Žiar $-1.5 \mathrm{~km}$ from the aluminium plant, Jalná $-7 \mathrm{~km}$ and Kováčová - 18 km.

The analysis of 2004 data revealed a significant decrease in necrotic disease of stems in $2^{\text {nd }}$ and $3^{\text {rd }}$ tree classes with the increasing distance from the pollution source. This trend was confirmed in 2014, but only in the $3^{\text {rd }}$ tree class. We observed a decline in the disease of beech crowns, but it was not statistically significant.

From 2004 (2007) to 2014, a decline in the index values of stems $\left(\mathrm{I}_{\mathrm{SN}}\right)$, crowns $\left(\mathrm{I}_{\mathrm{CN}}\right)$, and the whole trees $\left(\mathrm{I}_{\mathrm{WTN}}\right)$ was recorded everywhere, except for a slight, insignificant increase of $\mathrm{I}_{\mathrm{CN}}$ at Jalná. On the other hand, at Žiar, all index values were higher compared to Jalná and Kováčová, which may have been related to the longer distance from the pollutant source.

We could not confirm the first hypothesis that the values of necrotization of beech stems and crowns will increase over time due to the new technology for aluminium production (Table 2). We confirmed the second hypothesis that the locality, which was situated nearest to the source of the pollutant load (Žiar) had a higher incidence of BBD over the study period (Fig. 2, Table 5). The third hypothesis was confirmed: the relationship between the necrotic disease of a beech stem and its crown was significant at all localities (Fig. 3).

\section{Acknowledgements}

This work was supported by the Scientific Grant Agency VEGA of the Slovak Academy of Sciences (project No. 2/0101/18). The authors would like to thank Robert Morrissey for language corrections and comments.

\section{Conflict of Interest}

The authors declare no conflict of interest.

\section{References}

1. MIHÁL I., CICÁK A., TSAKOV H. Beech (Fagus sylvatica L.) bark necrotic damage as a serious phytopathological problem in Central and South-eastern Europe. J. For. Sci. 61, 7, 2015.
2. GIENCKE L.M., DOVČIAK M., MOUNTRAKIS G., CALE J.A., MITCHELL M.J. Beech bark disease: spatial patterns of thicket formation and disease spread in an aftermath forest in the north-eastern United States. Can. J. For. Res. 44, 1042, 2014.

3. CALE J.A., LETKOWSKI S.K., TEALE S.A., CASTELLO J.D. Beech bark disease: an evaluation of the predisposition hypothesis in an aftermath forest. Forest Pathol. 42, 52, 2012.

4. HECHT U., KOHNLE U., NILL M., GRÜNER J., METZLER B. Bark wounds caused by felling are more susceptible to discoloration and decay than wounds caused by extraction in European beech. Ann. For. Sci. 72, 731, 2015.

5. ŠPULÁK O., SOUČEK J. The Sibyla model and development of beech forests affected by air pollution. Centr. Eur. J. Biol. 5, 371, 2010.

6. HORNTVEDT R. Accumulation of airborne fluorides in forest trees and vegetation. Eur. J. For. Pathol. 27, 73, 1997.

7. GARCÍA-GIL J.C., KOBZA J., SOLER-ROVINA R., JAVOREKOVÁ S. Soil microbial and enzyme activities response to pollution near aluminium smelter. Clean - Soil Air Water 41, 485, 2013.

8. CUSKE M., KARCZEWSKA A., GAŁKA B., MATYJA K. Would forest litter cause a risk if increased copper solubility and toxicity in polluted soils remediated via phytostabilization? Pol. J. Environ. Stud. 26, 419, 2017.

9. ŚWIERKOSZ K., RECZYŃSKA K., KURAS I. Increasing area of deciduous forest communities (QuercoFagetea Class) as an unintended effect of regular forestry management - a study from Central Europe. Pol. J. Environ. Stud. 26, 323, 2017.

10. CICÁK A., MIHÁL I., TSAKOV H., PETKOV P. Methods of a complex evaluation of the necrotic disease of beech. J. For. Sci. 53, 460, 2007.

11. CICÁK A., MIHÁL I. Development of beech necrotic disease in the growing phase of maturing stand under influence of immission impact. J. For. Sci. 51, 101, 2005.

12. MIHÁL I., CICÁK A. Comparison of the status of beech necrotic disease at the locality Hiencová (Stolické vrchy Mts). Reussia 4, 29, 2007. [In Slovak].

13. RAČKO V., MIŠÍKOVÁ O. Formation of barrier zones of beech (Fagus sylvatica L.) inducted by injury. Acta Fac. Xylol. 57, 5, 2015 [In Slovak].

14. JARČUŠKA B., MIHÁL I., CICÁK A., TSAKOV H. Beech bark necrosis: partitioning the environmental and spatial distribution of the damage severity in Central and South-Eastern Europe. Ann. For. Res. 56, 317, 2013.

15. ŠTEFANČÍK I. A comparison with different tending variants in beech stands by the crown thinning and from the view of their quantitative and qualitative development. Centr. Eur. For. J. 63, 10, 2017.

16. RAČKO V., MIŠÍKOVÁ O. Formation of barrier zones of beech (Fagus sylvatica L.) inducted by injury. Acta Fac. Xylol. Zvolen. 57, 5, 2015. [In Slovak].

17. MIŠÍKOVÁ O., MIHÁL I., RAČKO V. Alterations in wood and bark structure of apple tree (Malus domestica) caused by Neonectria ditissima fungus. Acta Fac. Xylol. Zvolen. 60, 5, 2018.

18. JUNG T., VETTRAINO A.M., CECH T.L., VANNINI A. The impact of invasive Phytophthora species on European forests. In: Lamour K. (ed.), Phytophthora: A Global Perspective. CABI, Wallingford, UK, 166, 2013.

19. ORLIKOWSKI L.B., OSZAKO T., SZKUTA G. First record of Phytophthora spp. associated with the decline of 
European beech stands in south-west Poland. Phytopathol. Polonica 42, 37, 2006.

20. CICÁK A., MIHÁL I. Health status and mycoflora of unmixed beech stand in areas with different immission load. Lesn. Čas. - For. J. 42, 145, 1996 [In Slovak].

21. DITMAROVÁ L., KMEŤ J. Physiological and biochemical aspects of stress impact of beech samplings growing under varying site conditions. Biologia (Bratislava) 57, 533, 2002.

22. JAMNICKÁ G., BUČINOVÁ K., HAVRANOVÁ I., URBAN A. Current state of mineral nutrition and risk elements in a beech ecosystem situated near the aluminium smelter in Žiar nad Hronom, Central Slovakia. For. Ecol. Manage. 248, 26, 2007.

23. KOBZA J., GAŠOVÁ K. Soil Monitoring System as a Basic Tool for Protection of Soils and Sustainable Land Use in Slovakia. J. Agric. Sci. Technol. A4, 504, 2014.

24. ŠTEFANČÍK I., MIHÁL I. Effect of immission load on forest stands in the Žiarska kotlina basin. Čistota ovzdušia 23, 7, 1991 [In Slovak].

25. KUKLA J., JANÍK R., SCHIEBER B., KELLEROVÁ D., BUBLINEC E., BIČÁROVÁ S. Immission-load-related dynamics of $\mathrm{S}_{-} \mathrm{SO}_{4}^{2-}$ in precipitation and in lysimetric solutions penetrating through beech ecosystems. Folia Oecol. 44, 96, 2017.

26. GAŠOVÁ K., KUKLOVÁ K., KUKLA J. Contents of nutrients and arsenic in litterfall and surface humus in mature nudal beech stands subjected to different emissionimmission loads. Folia Oecol. 44, 11, 2017.

27. ŠTEFANČÍK I., BOŠEL'A M. An influence of different thinning methods on qualitative wood production of European beech (Fagus sylvatica L.) on two euthropic sites in the Western Carpathians. J. For. Sci. 60, 406, 2014.

28. BARNA M. Process of twig growth of beech (Fagus sylvatica L.) of dominant and codominant trees after regeneration cutting. Ekológia (Bratislava) 18, 233, 1999.

29. BARNA M., SCHIEBER B., CICÁK A. Effect of postcutting changes in site conditions on the morphology and phenology of naturally regenerated beech seedlings (Fagus sylvatica L.). Pol. J. Ecol. 57, 461, 2009.

30. SEIDEL D., HOFFMANN N., EHBRECHT M., JUCHHEIM J., AMMER CH. How neighborhood affects tree diameter increment - New insights from terrestrial laser scanning and some methodical considerations. For. Ecol. Manage. 336, 119, 2015.

31. CICÁK A., MIHÁL I. Bark necrosis index of beech stems. Lesnictví - Forestry 44, 474, 1998 [In Slovak].
32. ZAR J. H. Biostatistical Analysis. Prentice Hall, New Jersey, 663, 1999.

33. PERSIANI A.M., LOMBARDI F., LUNGHINI D., GRANITO V.M., TOGNETTI R., MAGGI O., PIOLI S., MARCHETTI M. Stand structure and deadwood amount influences saproxylic fungal biodiversity in Mediterranean mountain unmanaged forests. iForest 9, 115, 2016.

34. LUCHI N., CAPRETTI P., FEDUCCI M., VANNINI A., CECCARELLI B., VETTRAINO A.M. Latent infection of Biscogniauxia nummularia in Fagus sylvatica: a possible bioindicator of beech health conditions. iForest, 9, 49, 2015.

35. SAMEC P., FORMÁNEK P. Microbiology of forest soils. Lesn. Práce. 126, 2011 [In Czech].

36. CICÁK A., KELLEROVÁ D., KULFAN J., MIHÁL I. Air pollution - harmful factor, In: Barna M., Kulfan J., Bublinec E. (eds), Beech and Beech Ecosystems of Slovakia. Veda, Bratislava, 2011. [In Slovak].

37. MIHÁL I., BLANÁR D., GLEJDURA S. Enhancing knowlegde of mycoflora (Myxomycota, Zygomycota, Ascomycota, Basidiomycota) in oak-hornbeam forests in the vicinity of the magnesite plants of Lubeník and Jelšava (Central Slovakia). Thaiszia - J. Bot. 25, 121, 2015.

38. BLANÁR D., MIHÁL I., UJHÁZY K., GUTTOVÁ A. Impact of magnesite immissions on the species composition of oak-hornbeam forests. Bull. Slov. Bot. Spol., 38 (1), 127, 2016 [In Slovak].

39. BRUNNER I., SPERISEN C. Aluminium exclusion and aluminium tolerance in woody plants. Front. Plant Sci. 4, 172, 12, 2013.

40. CICÁK A., MIHÁL I. Current state of beech bark necrotic disease in Southern Poland. J. For. Sci. 54, 459, 2008.

41. CICÁK A., MIHÁL I., TSAKOV H., PETKOV P. Methods of complex evaluation of the necrotic disease of beech. J. For. Sci. 53, 642, 2007.

42. MAB STRATEGY. In: [online] http://www.unesco.org/ new/en/natural-sciences/environment/ecological-sciences/ man-and-biosphere-programme/strategies-and-actionplans/new-mab-strategy-and-action-plan

2015-2025, (access 05. 05. 2015)

43. MIHÁL I., ČERNECKÁ L'. Structure of harvestmen (Arachnida, Opiliones) communities in different, anthropically disturbed beech ecosystems (Western Carpathians, Slovakia). Vestnik zoologii, 51, 259, 2017. 